\title{
Pengaruh Model Pembelajaran Aktif Berbasis Inkuiri (ABI) Terhadap Kemampuan Berpikir Kritis Siswa
}

\author{
Indah Dharmawati ${ }^{\left.1^{*}\right)}$, Saiful Prayogi ${ }^{2)}$, Samsun Hidayat ${ }^{3)}$ \\ ${ }^{1,2 \& 3)}$ Program Studi Pendidikan Fisika, FPMIPA, IKIP Mataram \\ *Email: indahdharmawati120@gmail.com
}

\section{Article History}

Received: April 2018

Reviewed: May 2018

Published: June 2018

Key Words

Active Learning;

Inquiry Based Active

Learning Model (ABI);

Critical Thinking Ability

Sejarah Artikel

Diterima: April 2018

Direviu: Mei 2018

Dipublikasi: Juni 2018

Kata Kunci:

Pembelajaran Aktif;

Model Pembelajaran Aktif

Berbasis Inkuiri (ABI);

Kemampuan Berpikir

Kritis

How to cite this article?

\begin{abstract}
[Title: The Effect of Inquiry-Based Active Learning (ABI) on Students' Critical Thinking Ability]. The critical thinking ability is the ability to learn and analyze information through skills: interpretation, analysis, evaluation, inference, explanation and self-regulation. Inquiry-based active learning model (ABI) is a learning model that accumulates active and inquiry learning which aims to develop students critical thinking ability through phases: 1) introduction and establishing sets; 2) presenting cognitive conflicts; 3) submitting the hypothesis; 4) collecting data (experiment) for hypothesis testing; 5) formulate explanations and/or conclusions; 6) reflection. This research aims to determine the effect of inquiry-based active learning model (ABI) on students' critical thinking ability. This research is quantitative research (quasi-experiments), this experimental research uses pretest-posttest control group design. This research is used cluster random sampling. The sample in this research amounted to 37 students as experimental class and 34 students as control class. The inferential analysis is used to test the influence of inquiry-based active learning model (ABI) in a review of improvement of students' critical thinking ability. Hypothesis test results also show t-test value lower than t-table value, so it can be stated that the Inquiry-Based Aktive Learning Model (ABI) has a positive effect on critical thinking ability of X-GEO at SMKN 3 Mataram school year 2017/2018.
\end{abstract}

\begin{abstract}
Abstrak
Kemampuan berpikir kritis merupakan kemampuan untuk mengevaluasi dan menganalisis informasi melalui keterampilan-keterampilan: interpretasi, analisis, evaluasi, inferensi, ekspalanasi dan pengaturan-diri. Model Pembelajaran Aktif Berbasis Inkuiri (ABI) merupakan suatu model pembelajaran yang mengakumulasi pembelajaran aktif dan inkuiri yang bertujuan untuk mengembangkan keterampilan berpikir kritis siswa melalui fase-fase: 1) Introduksi dan Establishing set; 2) Mempresentasikan konflik kognitif; 3) Mengajukan hipotesis; 4) Mengumpulkan data (eksperimen) untuk menguji hipotesis; 5) Merumuskan penjelasan dan atau kesimpulan; 6) Refleksi. Penelitian ini bertujuan untuk mengetahui pengaruh model pembelajaran aktif berbasis inkuiri (ABI) terhadap kemampuan berpikir kritis siswa. Penelitian ini merupakan penelitian kuantitatif (quasiexperiments), desain pretest-posttest control group design. Cara atau teknik pengambilan sampel pada penelitian ini adalah clasterrandom sampling. Sampel pada penelitian ini berjumlah 37 siswa untuk kelas eksperimen dan 34 siswa untuk kelas kontrol. Analisis inferensial digunakan untuk menguji pengaruh model pembelajaran $\mathrm{ABI}$ terhadap kemampuan berpikir kritis siswa ditinjau dari peningkatan kemampuan berpikir kritis siswa. Hasil pengujian hipotesis menunjukkan nilai t-test lebih rendah dari nilai t-tabel, sehingga dapat dinyatakan bahwa model pembelajaran Aktif Berbasis Inkuiri berpengaruh positif terhadap kemampuan berpikir kritis siswa kelas X GEO SMKN 3 Mataram tahun pelajaran 2017/2018.
\end{abstract}

Dharmawati, I., Prayogi S., Hidayat, S. (2018). Pengaruh Model Pembelajaran Aktif Berbasis Inkuiri (ABI) Terhadap Kemampuan Berpikir Kritis Siswa. Lensa: Jurnal Kependidikan Fisika, 6(1), 8-17. 


\section{PENDAHULUAN}

Seorang guru dalam pembelajaran diwajibkan menggunakan model pembelajaran yang lebih banyak melibatkan siswa untuk aktif, dengan kata lain seorang guru dalam pembelajaran harus mengembangkan strategi mengajar yang mengarah pada keaktifan belajar siswa (student center). Model pembelajaran mengarahkan kita dalam merancang pembelajaran untuk membantu peserta didik mencapai tujuan pembelajaran, dengan model pembelajaran tersebut guru dapat membantu siswa untuk mendapatkan ide, keterampilan, cara berpikir dan mengekspresikan ide diri (Tritanto, 2007).

Permasalahan yang umum terjadi dalam pembelajaran sains termasuk di dalamnya pembelajaran fisika menurut (Heuvelen, 2001 dalam prayogi), yaitu pembelajaran selama ini terlalu banyak menyajikan pengetahuan. Jadi, terlalu banyak membahas fakta dan hukum, dan kurang sekali menerapkan metode inkuiri yang efektif untuk menemukan konsep atau hukum dalam suatu pokok bahasan. Siswa belajar konsep malalui membaca buku atau mendengarkan penjelasan guru. Kepercayaan siswa terhadap sains dibentuk melalui pemberitahuan orang lain, tidak melalui pengamatan atau pemodelan yang dilakukan sendiri.

Kemendikbud (2013) dalam pemaparannya menyatakan, proses pembelajaran pada kurikulum 2013 ditekankan pada pendekatan scientific (ilmiah). Kriteria scientific dimaksudkan untuk mendorong pebelajar berpikir kritis, analitis dan tepat dalam mengidentifikasi, memahami, memecahkan masalah, dan mengaplikasikan materi pembelajaran. Agar disebut scientific, maka kegiatan pembelajaran diarahkan pada pembelajaran yang berbasis pada kegiatan inkuiri ilmiah. Pendekatan scientific juga harus mendorong interaksi edukatif guru dengan pebelajar secara aktif (Atsnan dan Gazali, 2013).

Dari permasalah dan tuntutan Pendidikan nasional, maka penting untuk menerapkan model pembelajaran yang berorientasi pada siswa. Mata pelajaran fisika tidak hanya melatih kemampuan kognitif siswa tetapi bagaimana siswa mampu terlibat aktif dalam pembelajaran. Siswa tidak hanya dituntut untuk menyelesaikan konsep fisika menggunakan persamaan matematis saja, tetapi bagaimana siswa mampu berpikir bahwa konsep tersebut dapat digunakan dalam kehidupan nyata, untuk itu siswa diperlukan terlibat aktif dalam pembelajaran, sehingga hal-hal yang belum terjawab bisa dipecahkan menggunakan model pembelajaran misalnya model pembelajaran inkuiri.

Kegiatan inkuiri merupakan proses umum yang biasa dilakukan oleh manusia untuk mencari atau memahami informasi, dalam pembelajaran inkuiri mengutamakan siswa sebagai pelaku utamanya, siswa bebas mengeluarkan pendapat dan berkomentar mengenai permasalahan-permasalahan yang diajukan oleh guru. Pembelajaran ini dirancang secara khusus mengajak siswa untuk terlibat secara langsung dalam proses ilmiah dalam waktu yang relative singkat dan membantu para siswa belajar merumuskan dan menguji pendapatnya sendiri (Samdas, 2012).

Penguasaan materi fisika menuntut kemampuan berpikir logis dan kritis, oleh karena itu model yang diterapkan hendaknya memfasilitasi aktivitas berpikir siswa. Titik berat yang menyebabkan lemahnya kualitas pembelajaran, yaitu berakar dari lemahnya proses pembelajaran yang tidak mendorong pebelajar untuk berpikir kritis (Ariyati, 2010). Berpikir kritis telah menjadi bagian yang sangat penting sebagai salah satu tujuan pembelajaran dalam Kurikulum 2013 di Indonesia, sehingga siswa mampu mengembangkan kemampuan berpikir kritisnya. Namun, yang menjadi kenyataan berdasarkan hasil observasi yang pernah dilakukan peneliti menemukan bahwa kebanyakan siswa kurang memahami konsep berpikir kritis walaupun secara tidak sadar mereka sebenarnya berpikir kritis dalam beberapa hal saat pembelajaran terjadi. Hal ini dikarenakan guru kurang bahkan tidak mengajarkan dan melatihkan berpikir kritis, dan pembelajaran yang dilakukan kurang memfasilitasi pebelajar untuk berpikir kritis. Di samping itu, guru juga kurang memahami bagaimana mengajarkan keterampilan berpikir kritis dalam suatu desain model pembelajaran (Prayogi, 2013). Kenyataan ini tentu sangat memprihatinkan, bahwa berpikir kritis semestinya harus diajarkan dan dilatihkan pada tataran siswa.

Melibatkan peserta didik dalam inkuiri memungkinkan peserta didik untuk terlibat dalam proses mental yang tinggi (penalaran) dan mengambil keputusan. Sepanjang proses inkuiri, para 
guru dan peserta didik didorong untuk berpikir kritis, aktif, terbuka, dan yang paling penting keingintahuan tentang lingkungan belajar. Peserta didik menjadi lebih sadar bahwa mereka bertanggung jawab atas temuan mereka sendiri. Proses inkuiri memiliki potensi untuk mengembangkan keterampilan, dan disposisi untuk belajar seumur hidup, misalnya, kemandirian, keterampilan berpikir, kepercayaan diri, pengambilan keputusan, pembelajaran kooperatif dan terlibat aktif dalam pembelajaran. Model Pembelajaran Aktif Berbasis Inkuiri (ABI) merupakan suatu model pembelajaran yang mengakumulasi pembelajaran aktif dan inkuiri yang bertujuan untuk mengembangkan keterampilan berpikir kritis siswa melalui fasefase: 1) Introduksi dan Establishing set; 2) Mempresentasikan konflik kognitif; 3) Mengajukan hipotesis; 4) Mengumpulkan data (eksperimen) untuk menguji hipotesis; 5) Merumuskan penjelasan dan atau kesimpulan; 6) Refleksi (Prayogi dan Muhali, 2016). Model ABI sebagai salahsatu model pembelajaran alternatif untuk melatih kemampuan berpikir kritis pentng untuk diuji efektifitasnya dibandingkan model-model student oriented sehingga dapat direkomendasikan sebagai model yang dapat digunakan untuk membelajrkan kemampuan berpikir kritis siswa seperti diamanatkan Permendiknas (2015) bahwa siswa seharusnya diajarkan keterampilan-keterampilan hidup dalam proses pembelajaran.

Penelitian ini bertujuan untuk mengetahui pengaruh model pembelajaran Aktif Berbasis Inkuiri (ABI) terhadap kemampuan berpikir kritis siswa. Indikator kemampuan berpikir kritis dalam penelitian ini meliputi: interpretasi, analisis, evaluasi, inferensi, ekspalanasi dan pengaturan-diri.

\section{METODE}

Penelitian ini merupakan penelitian kuantitatif (quasi-experiments) atas dasar data-data hasil belajar yang dikumpulkan berupa angka-angka yang kemudian dianalisis secara kualitatif. Desain penelitian eksperimen ini, menggunakan pretest-posttest control group design.Cara atau teknik pengambilan sampel pada penelitian ini adalah clasterrandom sampling yaitu pengambilan sampel dilakukan secara acak tanpa memperhatikan strata yang ada dalam populasi itu, dari jumlah populasi yang ada pada siswa kelas X SMKN 3 Mataram yang terdiri dari 18 kelas.Maka diambil 2 kelas secara acak dan kelas yang terpilih adalah kelas X GEO dan kelas X TKRO. Selanjutnya 2 kelas tersebut kemudian diundi untuk dijadikan kelas eksperimen dan kelas kontrol.

Analisis inferensial digunakan untuk menguji pengaruh model pembelajaran ABI terhadap kemampuan berpikir kritis siswa ditinjau dari peningkatan kemampuan berpikir kritis siswa. Data yang dianalisis adalah hasil pretest dan posttest yang diperoleh siswa, dengan menggunakan analisis statistik. Analisis signifikansi peningkatan hasil pretes dan posttest dilakukan setelah melalui uji prasyarat yaitu uji normalitas data dan uji homogenitas varians. Jika data terdistribusi normal dan homogen maka analisis selanjutnya dilakukan dengan menggunakan statistik parametrik, sebaliknya jika data terdistribusi tidak normal maka digunakan analisis statistik non-parametrik, dengan bantuan program SPSS v.17 for windows, mengikuti alur analisis yang disajikan pada Gambar 1. 


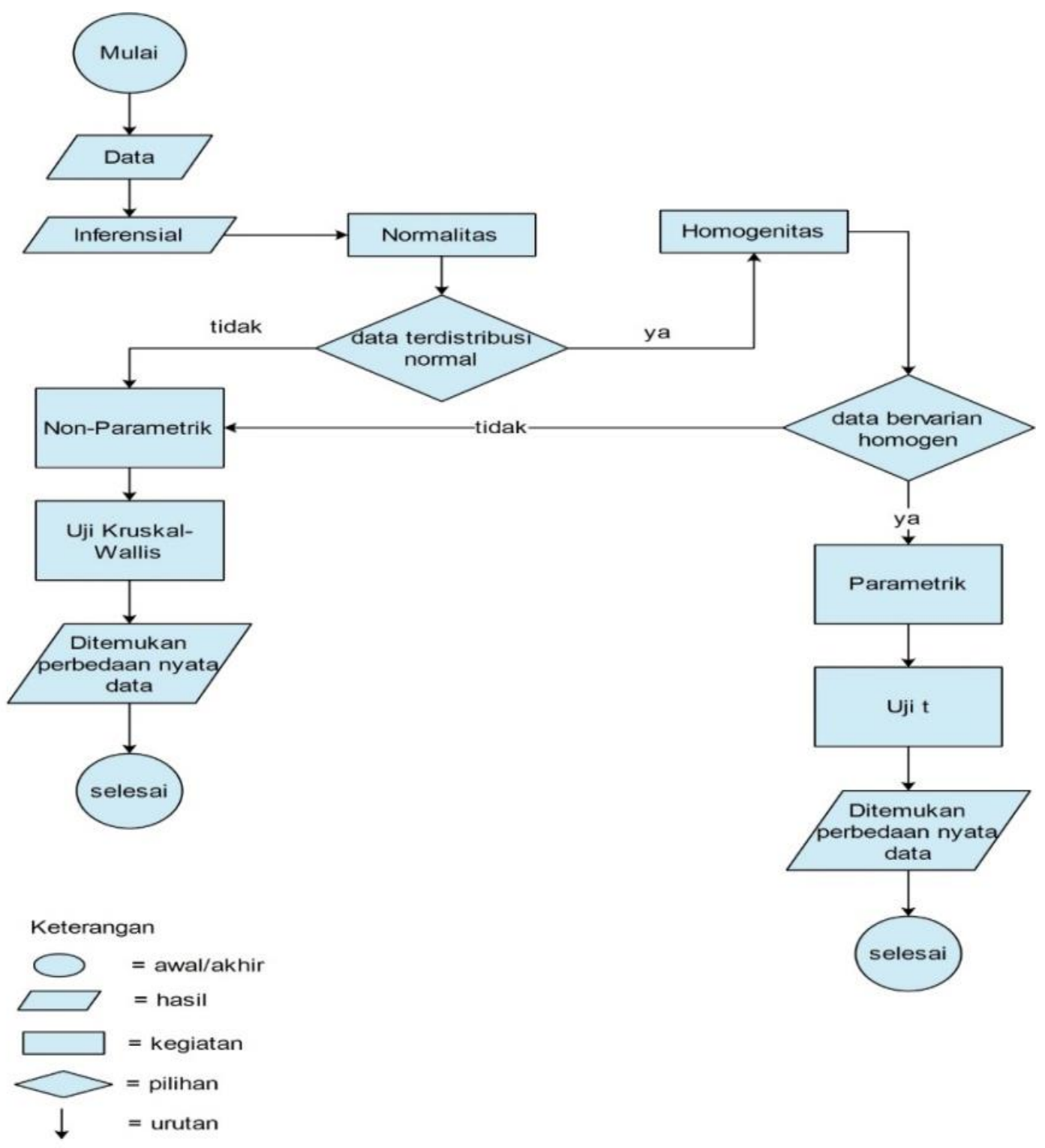

Gambar 1. Alur Uji Pengaruh Model Pembelajaran ABI terhadap Kemampuan Berpikir Kritis Siswa

\section{HASIL PENELITIAN DAN PEMBAHASAN}

Penelitian ini telah dilaksanakan di SMK Negeri 3 Mataram pada tanggal 24 Januari sampai dengan 7 Februari 2018. Populasi penelitian adalah siswa kelas X SMK Negeri 3 Mataram tahun ajaran 2017/2018 yang terdiri dari 18 kelas. Pengambilan sampel pada penelitian ini menggunakan teknik Claster Random Sampling. Sampel penelitian adalah kelas X Geomatika sebagai kelas eksperimen yang berjumlah 37 orang siswa terdiri atas 31 orang lakilaki dan 6 orang perempuan sedangkan sampel untuk kelas kontrol adalah kelas X TKRO (Teknik Kendaraan Ringan Otomotif) yang berjumlah 34 orang siswa terdiri atas 34 orang lakilaki.

Data hasil belajar dengan pembelajaran menggunakan model pembelajaran Aktif Berbasis Inkuiri (ABI) dan pembelajaran menggunakan model pembelajaran kooperative diperoleh dari skor rata-rata post test setiap kelas ujicoba. Penelitian ini dilakukan dalam dua kali pertemuan. Materi ajar pada pertemuan pertama adalah Menjelaskan karakteristik gelombang mekanik dan elektromagnetik, Menjelaskan karakteristik gelombang transversal dan longitudinal, Menentukan frekuensi gelombang elektromagnetik, Menjelaskan sifat-sifat pemantulan gelombang (refleksi), Menjelaskan sifat-sifat pembiasan gelombang (refraksi), Menjelaskan sifat- 
sifat perpaduan gelombang (interferensi), Menjelaskan sifat-sifat lenturan gelombang (difraksi), Menentukan periode, frekuensi dan cepat rambat gelombang, pada pertemuan kedua tentang Gelombang Bunyi. Awal pertemuan, siswa diberikan pretest untuk mengetahui kemampuan awal siswa tentang materi yang akan diajarkan sebelum mengikuti pembelajaran, dan diberikan posttest pada akhir pembelajaran untuk mengetahui sejauh mana siswa menguasai materi yang telah diajarkan. Selanjutnya data skor pretest dan posttest tersebut diolah untuk mendapatkan hasil uji hipotesis.

Data skor pretest dan posttest siswa diukur menggunakan instrument berbentuk soal uraian (essay) yang hasil validitas ahli dan reliabilitas penilaian 2 (dua) validator instrument disajikan pada Tabel 1 berikut.

Tabel 1. Validitas dan Reliabilitas Butir Soal

\begin{tabular}{|c|c|c|c|c|c|c|c|c|}
\hline \multirow{4}{*}{$\begin{array}{l}\text { Nomor butir } \\
\text { soal }\end{array}$} & \multicolumn{8}{|c|}{ Aspek yang Dinilai } \\
\hline & \multicolumn{4}{|c|}{ Validasi Isi } & \multicolumn{4}{|c|}{ Validasi Bahasa dan Penulisan Soal } \\
\hline & \multicolumn{2}{|c|}{ Penilaian } & \multirow{2}{*}{$\begin{array}{l}\text { Rata- } \\
\text { rata } \\
\text { Skor }\end{array}$} & \multirow[b]{2}{*}{ Kategori } & \multicolumn{2}{|c|}{ Penilaian } & \multirow{2}{*}{$\begin{array}{l}\text { Rata- } \\
\text { rata } \\
\text { Skor }\end{array}$} & \multirow[t]{2}{*}{ Kategori } \\
\hline & V1 & V2 & & & V1 & V2 & & \\
\hline 1 & 4 & 4 & 4 & Sangat baik & 4 & 4 & 4 & Sangat baik \\
\hline 2 & 3 & 4 & 3,5 & Baik & 3 & 3 & 3 & Baik \\
\hline 3 & 4 & 4 & 4 & Sangat Baik & 4 & 4 & 4 & Sangat Baik \\
\hline 4 & 4 & 4 & 4 & Sangat Baik & 4 & 4 & 4 & Sangat Baik \\
\hline 5 & 4 & 4 & 4 & Sangat Baik & 4 & 4 & 4 & Sangat Baik \\
\hline 6 & 4 & 4 & 4 & Sangat baik & 3 & 4 & 3,5 & Baik \\
\hline Jumlah & 23 & 24 & 23.5 & & 22 & 23 & 22.5 & \\
\hline $\begin{array}{l}\text { Rata-rata } \\
\text { nilai aspek }\end{array}$ & 3.8 & 4 & 3.92 & Sangat baik & 3.67 & 3.83 & 3.75 & Sangat baik \\
\hline Reliabilitas & $98,7($ & & & Reliabel & 98,66 & & & Reliabel \\
\hline
\end{tabular}

Keterangan: V1: validator 1, V2: validator 2

Tabel 1, di atas menunjukkan secara keseluruhan penilaian validator terhadap instrumen kemampuan berpikir kritis yang digunakan dalam penelitian baik dari aspek isi, bahasa, maupun penulisan masuk dalam kategori sangat baik dengan nilai 3,85. Hasil validasi ini menunjukkan bahwa instrumen kemampuan berpikir kritis yang digunakan valid digunakan pada penelitian.

\section{Deskripsi Hasil Penelitian}

Rata-rata hasil pretest dan posttest siswa kelas eksperimen dan kelas kontrol dalam penelitian ini disajikan pada Tabel 2.

Tabel 2. Rekapitulasi Hasil Pretest dan Posttest Kelas Eksperimen

\begin{tabular}{lll}
\hline Data & Kelas Eksperimen (X Geo) & Kelas Kontrol (X TKRO) \\
\hline Jumlah siswa & 37 & 34 \\
\hline Nilai tertinggi posttest & 75 & 66,6 \\
\hline Nilai terendah posttest & 58,3 & 54,1 \\
\hline Nilai rata-rata posttest & 65,7 & 61,2 \\
\hline Nilai rata-rata pretest & 47,8 & 33,4 \\
\hline
\end{tabular}

\section{Data Pre-Test}

Data awal diambil dari nilai pre-test yang diberikan sebelum perlakuan, pre-test digunakan untuk mengetahui kemampuan awal siswa dari kedua sampel. Data hasil pre-test sampel disajikan secara ringkas pada Tabel 3 berikut.

Tabel 3. Daftar Nilai Pre-Test Kelas Kontrol dan Eksperimen

\begin{tabular}{llc}
\hline Kelas & Jumlah Siswa & $\bar{X}$ \\
\hline Eksperimen & 37 & 47.8 \\
Kontrol & 34 & 33.4 \\
\hline
\end{tabular}


Data pretest siswa dianalisis varians untuk menentukan homogenitas pengetahuan awal siswa. Hasil perhitungan data awal untuk uji homogenitas sampel disajikan sebagai berikut.

Tabel 4. Analisis Uji Homogenitas

\begin{tabular}{lllllr}
\hline & Levene Statistic & df1 & df2 & Sig. \\
\hline nilai & Based on Mean & 3.046 & 1 & 65 & .086 \\
& Based on Median & 4.002 & 1 & 65 & .050 \\
& Based on Median and with adjusted df & 4.002 & 1 & 63.424 & .050 \\
Based on trimmed mean & 3.611 & 1 & 65 & .062 \\
\hline
\end{tabular}

Data homogen mempunyai nilai Sig. Based on Mean $>$ alfa pengujian (0.05). Berdasarkan hasil analisis yang disajikan pada Tabel 4.5 tersebut dapat dinyatakan bahwa varians data pretest siswa homogeny, karena nilai Sig. $(0.086)>$ dari alfa pengujian $(0.05)$, sehingga dapat dinyatakan bahwa kedua sampel yaitu kelas eksperimen dan kelas kontrol memiliki kemampuan yang seragam atau homogen.

2. Data Hasil Post-test

Dari hasil post-test diperoleh data sebagai berikut.

Tabel 5.Daftar Nilai Post-Test Kelas Kontrol dan Eksperimen

\begin{tabular}{lll}
\hline Kelas & Jumlah Siswa & $\bar{X}$ \\
\hline Eksperimen & 37 & 65.79 \\
Kontrol & 34 & 61.2 \\
\hline
\end{tabular}

Berdasarkan Tabel 5 di atas dapat dilihat bahwa ada peningkatan nilai rata-rata siswa setelah diberi perlakuan dengan menggunakan model pembelajaran ABI. Dimana nilai rata-rata siswa kelas $\mathrm{X}$ GEO SMKN 3 Mataram sebelum diberi perlakuan (pre-test) yaitu kelas eksperimen sebesar 47.8 dan X TKRO BSMKN 3 Mataram yang merupakan kelas kontrol sebesar 33.4 sedangkan nilai rata-rata setelah perlakuan (post-test) yaitu kelas eksperimen sebesar 65.79 dan kelas kontrol sebesar 61.2.

3. Uji Normalitas

Uji statistik parametrik memiliki prasyarat untuk dilakukan yaitu data harus berdistribusi normal dan uji varians (homogenitas) jika jumlah sampel penelitian $<30$ sampel, jika hasil uji distribusi data dinyatakan tidak terdistribusi normal maka akan dilakukan uji statistik nonparametrik seperti alur yang disajikan pada Gambar1. Jumlah sampel yang di gunakan dalam penelitian ini adalah 34 siswa kelas esperimen dan 34 siswa kelas kontrol, sehingga tidak perlu dilakukan uji varians data untuk selanjutnya dilakukan pengujian hipotesis statistik.

Data hasil post-test pada kelas eksperimen dan kontrol diuji distribusinya menggunakan uji Kolmogorov-Smirnov terlebih dahulu untuk mengetahui data yang diperoleh terdistribusi normal atau tidak. Adapun hasil pengujian data hasil posttest disajikan pada Tabel 6 berikut.

Tabel 6. Analisis Uji Normalitas Kelas Eksperimen dan Kelas Kontrol

\begin{tabular}{|c|c|c|}
\hline & & Unstandardized Residual \\
\hline $\mathrm{N}$ & & 34 \\
\hline \multirow[t]{2}{*}{ Normal Parameters $^{\mathrm{a}}$} & Mean & .0000000 \\
\hline & Std. Deviation & 3.46101080 \\
\hline \multirow[t]{3}{*}{ Most Extreme Differences } & Absolute & .227 \\
\hline & Positive & .227 \\
\hline & Negative & -.102 \\
\hline Kolmogorov-Smirnov Z & & 1.323 \\
\hline Asymp. Sig. (2-tailed) & & .060 \\
\hline
\end{tabular}

Tabel 6 menunjukkan bahwa nilai Sig. data posttest kelas eksperimen dan kontrol $(0.06)>$ alfa pengujian (0.05) sehingga dapat dinyatakan bahwa data tersebut berdistribusi normal. 


\section{Uji Hipotesis}

Hasil pengujian distribusi data posttest kelas eksperimen dan kelas kontrol dinyatakan terdistribusi nolmal, sehingga untuk menguji hipotesis statistik dalam penelitian ini dilakukan uji-t untuk mengetahui perbedaan hasil belajar siswa antara kelas eksperimen setelah pembelajaran menggunakan model pembelajaran Aktif Berbasis Inkuiri dan setelah pembelajaran kooperatif pada kelas kontrol. Data hasil pengujian pengaruh model permbelajaran Aktif Berbasis Inkuiri terhadap kemampuan berpikir kritis siswa disajikan pada Tabel 7 berikut.

Tabel 7. Analisis Uji Normalitas Kelas Eksperimen dan Kelas Kontrol

\begin{tabular}{|c|c|c|c|c|c|c|c|c|}
\hline & & \multicolumn{7}{|c|}{$\begin{array}{l}\text { Levene's } \\
\text { Test for } \\
\text { Equality of } \\
\text { Variances t-test for Equality of Means }\end{array}$} \\
\hline & & \multirow[b]{2}{*}{ Sig. } & \multirow[b]{2}{*}{$\mathrm{t}$} & \multirow[b]{2}{*}{$\mathrm{df}$} & \multirow{2}{*}{$\begin{array}{l}\text { Sig. } \\
(2- \\
\text { tailed })\end{array}$} & \multirow{2}{*}{$\begin{array}{l}\text { Mean } \\
\text { Difference }\end{array}$} & \multirow{2}{*}{$\begin{array}{l}\text { Std. Error } \\
\text { Difference }\end{array}$} & $\begin{array}{l}95 \% \text { Confidence } \\
\text { Interval of the } \\
\text { Difference }\end{array}$ \\
\hline & & & & & & & & Lower Upper \\
\hline \multirow[t]{2}{*}{ nilai } & $\begin{array}{l}\text { Equal } \\
\text { variances } \\
\text { assumed }\end{array}$ & 24.536 .000 & 3.808 & 66 & .000 & 4.33235 & 1.13775 & 2.060766 .60395 \\
\hline & $\begin{array}{l}\text { Equal } \\
\text { variances } \\
\text { not } \\
\text { assumed }\end{array}$ & & 3.808 & 55.300 & .000 & 4.33235 & 1.13775 & 2.052526 .61218 \\
\hline
\end{tabular}

Berdasarkan hasil pengujian seperti ditunjukkan pada Tabel 7, diketahui bahwa nilai Sig. (2-tailed) data posttest $(0.00)<$ alfa pengujian (0.05), sehingga dapat dinyatakan bahwa model pembelajaran Aktif Berbasis Inkuiri berpengaruh terhadapa kemampuan berpikir kritis siswa. Hasil tersebut menunjukkan bahwa $\mathrm{H}_{0}$ ditolak. Hal tersebut berarti ada pengaruh signifikan penggunaan model pembelajaran Aktif Berbasis Inkuiri terhadap kemampuan berpikir kritis siswa kelas X GEO SMKN 3 Mataram tahun pelajaran 2017/2018.

\section{Pembahasan}

Berdasarkan hasil analisis data penelitian yang telah disajikan pada bagian deskripsi data penelitian, maka dilakukan pembahasan atau diskusi terhadap hasil analisis tersebut baik yang berkaitan dengan kualitas buti perangkat pembelajaran pendukung model aktif berbasis ikuiri yang digunakan seperti validitas butir soal, handout, RPP, LKS, serta hasil uji hipotesis pengaruh model pembelajaran aktif berbasis inkuiri terhadap kemampuan berpikri kritis siswa pokok bahasan gelombang.

\section{Validitas Butir Soal}

Penilaian merupakan salah satu teknik yang digunakan untuk mengetahui tingkat pencapaian siswa. Penilaian dapat dilakaukan, jika tersedia instrumen/alat penilaian, baik menggunakan instrumen berupa tes, maupun berupa lembar pengamatan. Penilaian yang dilakukan dalam penelitian ini menggunakan instrumen tertulis, atau teknik penilaian menggunakan strategi tertulis dengan bentuk soal uraian untuk mengetahui kemampuan berpikir kritis siswa. Soal uraian yang digunakan terdiri dari 6 item pertanyaan yang harus dijawab siswa berdasarkan waktu yang telah ditentukan. Penskoran terhadap setiap respon atau jawaban yang diberikan siswa mengacu pada lembar penilaian berpikir kritis dengan 6 indikator yaitu 1) interpretasi, 2) analisis, 3) evaluasi, 4) inferensi, 5) eksplanasi, serta 6) regulasi-diri.

Instrumen yang telah disusun sebelum dapat digunakan sebagaimana fungsinya, yakni mengukur kemampuan berpikir kritis siswa, terlebih dahulu dilakukan uji kevalidan. Berdasarkan hasil uji validasi sebagaimana yang tampak pada Tabel 1 mendapatkan nilai 3,92 untuk komponen isi (berkategori sangat baik) dan nilai 3.75 untuk komponen Bahasa dan penulisan (berkategori sangat baik). Berdasarkan hasil validasi tersebut, instrumen yang telah dikembangkan valid digunakan pada tahap penelitian untuk mengukur kemampuan berpikir 
kritis siswa. Hasil validitas ini dikarenakan proses/prosedur penyusunan instrumen kemampuan berpikir kritis memenuhi persyaratan substansi, konstruksi, dan bahasa.

2. Pengaruh Model Pembelajaran Aktif Berbasis Inkuiri terhadap Kemampuan Berpikir Kritis Siswa

Peningkatan keterampilan berpikir kritis siswa (Tabel 2) diperoleh 65.79 untuk kelas eksperimen dan 61.2 untuk kelas kontrol dengan kategori untuk masing-masing kelas dikategorikan kritis. Dalam pandangan Piaget, pengetahuan datang dari tindakan, perkembangan kognitif sebagian besar bergantung pada seberapa jauh anak memanipulasi dan aktif berinteraksi dengan lingkungannya, guru diharuskan 1) memusatkan perhatian kepada cara berpikir atau proses mental anak, tidak sekedar kepada hasilnya. Disamping kebenaran jawaban siswa, guru harus memahami proses yang digunakan sehingga sampai pada jawaban tersebut, 2) mengutamakan peran siswa dalam berinisiatif sendiri dan keterlibatan aktif dalam dalam kegiatan pembelajaran. Anak didorong menemukan sendiri pengetahuan melalui interaksi spontan dengan lingkungannya, peserta didik hendaknya diberi kesempatan untuk melakukan eksperimen dengan objek fisik, yang ditunjang denagn interaksi dengan teman sebaya dan guru hendaknya banyak memberi dorongan agar siswa secara aktif berinteraksi dengan lingkungan untuk mencari dan menemukan berbagai hal dari lingkungan, 3) memaklumi akan adanya perbedaan individual dalam kemajuan perkembangan.

Proses pembelajaran aktif berbasis inkuiri yang berlangsung berpusat pada siswa (student centered). Siswa diberi kesempatan untuk terlibat secara aktif dalam belajar baik mental, intelektual, dan sosial emosional. Kegiatan pembelajaran yang berlangsung melibatkan secara maksimal seluruh kemampuan siswa untuk mencari dan menyelidiki secara sistematis, kritis, logis, dan analitis, sehingga mereka dapat merumuskan sendiri penemuannya dengan penuh percaya diri (Gulo, 2002; Sanjaya, 2009).

Pembelajaran dengan model inkuiri yang merupakan dasar penyusun model pembelajaran ABI menunjukkan hasil yang memuaskan karena pembelajaran tersebut dapat mempercepat proses ingatan dikarenakan pengetahuan yang diperoleh melalui proses penyelidikan akan lebih mudah diingat (Praptiwi, 2012). Hal ini didukung oleh pernyataan Amaliah (2008) bahwa peningkatan keterampilan berpikir dapat terjadi karena pembelajaran dengan model inkuiri dapat membuat siswa berpikir bagi dirinya sendiri, berperan serta dalam proses perolehan pengetahuan dan dalam pencarian konsep yang dipelajari sehingga retensi terhadap konsep yang didapatkan akan lebih lama dibanding dengan hanya mendapatkan konsep tersebut dari penjelasan guru.

Berdasarkan sintaks dalam strategi pembelajaran inkuiri sangat mendukung proses berpikir tingkat tinggi. Dalam tahapan rumusan masalah, guru dan siswa secara bersama-sama merumuskan masalah dari fenomena pada materi larutan penyangga. Partisipasi siswa dalam merumuskan masalah akan memberikan dampak yang signifikan bagi keberlangsungan proses pembelajaran kedepannya. Siswa mengajukkan pertanyaan atau permasalahan berdasarkan fenomena yang ada. Perumusan pertanyaan yang diajukkan siswa akan merangsang kemampuan berpikir kritis siswa. Dalam perumusan masalah, siswa akan mengoptimalkan pengetahuan awal yang dimiliki dengan cara mengingat kembali konsep-konsep terkait dengan materi sebelumnya. Pengetahuan awal yang dimiliki siswa akan memberikan dampak positif terhadap siswa, yaitu siswa akan lebih memperkuat konsep-konsep tersebut dalam memori jangka panjang.

Proses belajar yang dimulai dengan merumuskan masalah (pertanyaan-pertanyaan), kemudian mencari, menyelidiki dan menemukan sendiri jawaban dari suatu masalah yang dipertanyakan, akan memberikan kesempatan belajar yang lebih bermakna pada siswa. Dengan demikian pengetahuan dan keterampilan yang diperoleh siswa bukan dari mengingat atau menghafal seperangkat fakta, konsep, atau teori, tetapi dapat menemukan dan membangun atau mengkontruksi sendiri pengetahuan itu dan memberi makna melalui pengalaman nyata. Pada tahap selanjutnya yaitu mengajukan hipotesis terkait dengan permasalahan yang dirumuskan. Keterampilan berpikir kritis dan berpikir deduktif yang diperlukan berkaitan dengan pengumpulan data yang bertalian dengan kelompok hipotesis. Setelah mengajukan rumusan masalah dan hipotesis, dilakukan kegiatan pengumpulan data. 
Pada tahap pengumpulan data kemampuan berpikir kritis siswa akan lebih berkembang melalui pencarian sumber atau informasi yang relevan dengan rumusan masalah dan hipotesis yang dibuat. Proses pencarian informasi atau sumber yang relevan merupakan proses investigasi secara teoritik dari kemampuan berpikir kritis. Investigasi informasi yang relevan terkait dengan hipotesis yang diajukan akan memberikan kemampuan kepada siswa untuk menemukan sendiri jawabannya dan berpikir secara logis atau rasional dalam bentuk membandingkan, mengklasifikasikan, menunjukkan interaksi sebab-akibat, berpikir secara deduktif dan induktif, kemampuan memberikan analogi, serta mengkritisi informasi yang diperoleh yang semuanya akan bermuara pada peningkatan kemampuan berpikir kritis siswa.

Pada tahap penyimpulan, siswa akan melibatkan berbagai aspek dalam kemampuan berpikir kritis yaitu berpikir logis, proses induktif, deduktif, evaluatif, memberikan argumen yang logis dalam pengambilan keputusan. Seluruh aspek tersebut akan terakomodasi dalam diskusi interaktif saat masing-masing kelompok menyampaikan hasil pengamatan dan diskusinya. Guru dan siswa juga akan melakukan refleksi terhadap proses kegiatan pembelajaran guna memperbaiki dan menyempurnakan kegiatan pembelajaran berikutnya (Anggareni,2013).

Data pada Tabel 4.2 dan Tabel 4.3 menunjukkan bahwa kemampuan berpikir kritis mahasiswa cenderung meningkat dari kurang kritis menjadi kritis, sehingga dapat dinyatakan bahwa model pembelajaran ABI berpengaruh terhadap keterampilan berpikir kritis siswa. Hasil tersebut juga diperkuat dengan hasil uji statistik yang menunjukkan penggunaan model pembelajaran $\mathrm{ABI}$ perpengaruh signifikan terhadap kemampuan berpikir kritis siswa. Hasil ini tidak terlepas dari perangkat pendukung model ABI yang digunakan dalam pembelajaran. Sejalan dengan hasil tersebut Prayogi dan Muhali (2016) menyatakan bahwa meningkatkan keterampilan berpikir kritis siswa bergantung pada kualitas perangkat pendukung model.

Model pembelajaran ABI telah mengakomodasi beberapa rekomendasi dalam pembelajaran yang merupakan ide utama dalam pengembangan model ABI, antara lain melatih berpikir kritis dengan cara menyajikan pembelajaran dengan kasus/kontek dunia nyata, mendorong diskusi terbuka, dan mendorong kegiatan eksperimen berorientasi pada kegiatan inkuiri (Miri dkk., 2007; Fine dan Desmond, 2015; Samarapungavan dkk., 2008). Model pembelajaran ABI yang berbasis pada kegiatan inkuiri telah diintegrasikan dengan LKS (worksheet) yang diatribusi keterampilan proses sains. Menurut Sriarunrasmee dkk. (2015), keterampilan proses sains dapat menjadi alat untuk mengembangkan berpikir kritis.

Langkah-langkah pembelajaran dalam model ABI juga dirancang melatih berpikir kritis siswa, hal ini tercermin dari langkah pembelajaran yang menyajikan konflik kognitif di awal pembelajaran dan selanjutnya ditindaklanjuti dengan kegiatan eksperimen (inkuiri ilmiah). Konflik kognitif dilakukan dengan menyajikan data anomali dalam pembelajaran. Menyajikan informasi yang kontradiktif atau data anomali dipandang sebagai solusi yang dapat mengundang ketertarikan, memastikan pengetahuan awal itu muncul (Ambrose dan Lovett, 2014; Chinn dan Malhotra, 2002; Chinn dan Brewer, 1998). Menyajikan data anomali di sisi lain membantu pebelajar merefleksikan lebih lanjut tentang ide-ide mereka untuk memberikan penjelasan tentang fenomena yang dipelajari (Limon dan Carretero, 1997). Memberi penjelasan berdasarkan ide-ide atau fenomena yang dipelajari merupakan salah satu kajian dan menjadi indikator utama dalam berpikir kritis (Facione, 2011; Paul dan Elder, 2006).

\section{KESIMPULAN}

Berdasarkan hasil penelitian dan analisis data maka dapat disimpulkan bahwaterdapat pengaruh penggunaan Model Pembelajaran Aktif Berbasis Inkuiri (ABI) terhadap kemampuan berpikir kritis pada siswa kelas X SMKN 3 Mataram tahun pelajaran 2017/2018.

\section{SARAN}

Berdasarkan hasil penelitian yang telah dilakukan, beberapa saran dapat dikemukakan oleh peneliti antara lain:

1. Bagi siswaagar membudayakan belajar dan menggunakan media kontekstual serta mengkomunikasikannya dengan guru agar materi fisika lebih mudah dipahami. 
2. Kepada peneliti lainnya, hendaknya menggunakan media pembelajaran berupa handout berbasis model pembelajaran ABI dan agar lebih disempurnakan guna meningkatkan kemampuan berpikir kritis siswa pada pokok bahasan yang berbeda.

3. Bagi guru agar lebih berinisiatif untuk merancang dan menggunakan model-model inovatif serumpun dengan model pembelajaran $\mathrm{ABI}$ untuk meningkatkan berpikir kritis siswa.

\section{DAFTAR PUSTAKA}

Arends, R. (2012). Learning To Teach. Ninth Edition. New York: Mcgraw-Hill.

Ariyati, E. (2010). Pembelajaran Berbasis Praktikum Untuk Meningkatkan Kemampuan Berpikir Kritis Mahasiswa. Jurnal Matematika dan IPA. Vol. 1 No. 2.

Bailin, S., Case, Rs., Coombs, J. R., Daniels, L. B. (1999). Common Misconceptions of Critical Thinking. Journal of Curriculum Studies. 31(3),269-283.

Eggen, P \& Kauchak, D. (2012). Strategi dan Model Pembelajaran. Jakarta: Pearson Education Inc.

Facione, P. (2011). Critical Thinking. What it is and Why Its Counts. Measured Reason and The California Academic Press.

Fisher, A. (2003). Critical Thinking An Introduction. Cambridge: Cambridge University Press.

Heuvelen, A. V. (2001). Millikan Lecture 1999 : The Workplace, Student Minds, And Physics Learning. Am. J. Phys. 69(11).

Nieveen, N. (1999). Prototyping to Reach Product Quality. Kluwer Academic Publisher.

Pintrich, P. R. (1999). Motivational Beliefs as Resources for and Constraints on Conceptual Change. In W. Schnotz, S. Vosniadou, dan M. Carretero (Eds.), New perspectives on conceptual change. Amsterdam: Pergamon.

Prayogi, S. \& Muhali. (2015). Pengembangan Model Pembelajaran Aktif Berbasis Inkuiri (ABI) untuk Mengembangkan Keterampilan Berpikir Kritis Mahasiswa. Prisma Sains: Jurnal Pengkajian Ilmu dan Pembelajaran Matematika dan IPA IKIP Mataram. 3(1), 346-351.

Prayogi, S. (2013). Implementasi Model Inquiry untuk Mengembangkan Kemampuan Berpikir Kritis Mahasiswa Pendidikan Fisika. Laporan Hasil Penelitian. LPPM IKIP Mataram.

Prayogi, S., dan Asy'ari, M. (2013). Implementasi Model PBL (Problem Based Learning) untuk Meningkatkan Hasil Belajar dan Kemampuan Berpikir Kritis Siswa. Prisma Sains: Jurnal Pengkajian Ilmu dan Pembelajaran Matematika dan IPA IKIP Mataram, 1(1), 79-87.

Sanjaya, (2011). Strategi Pembelajaran Berorientasi Standar Proses Pendidikan. Jakarta: Kencana.

Samdas. G. (2012). Pembelajaran Inovatif. Lembaga Pengkajian Pembaharuan Hukum dan Kebijakan Publik (LP2HKP). Palu.

Syah, M. (2010). Psikologi Pendidikan .Bandung: Rosdakarya.

Sternberg, R. (1986). Critical thinking: its nature, measurement, and improvement. http://eric.ed.gov/PDFS/ED272882.pdf.

Usdalifat, S. (2016). Pengaruh Model Inkuiri Terhadap Kemampuan Berpikir Kritis dan keterampilan Proses Siswa Pada Mata Pelajaran IPA Kelas VII SMP Negeri 19 Palu. Jurnal Sains dan Teknologi tadulako, 5(3),-.

Thompson, C. (2011). Critical Thinking Across The Curriculum: Process Over Output. International Journal of Humanities and Social Science, 1(9),-.

Tritanto. (2007). Model Pembelajaran Terpadu dalam Teori dan Praktek. Jakarta: Prestasi Pustaka.

Woolfolk, A. (2009). Educational Psychology. Bagian Pertama. New York: Pearson. 